\title{
Total Organic Carbon Enrichment and Source Rock Evaluation of the Lower Miocene Rocks Based on Well Logs: October Oil Field, Gulf of Suez-Egypt
}

\author{
Aref Lashin ${ }^{1,2}$, Saad Mogren ${ }^{1}$ \\ ${ }^{1}$ Geology and Geophysics Department, College of Science, King Saud University, Riyadh, KSA \\ ${ }^{2}$ Geology and Geophysics Department, Faculty of Science, Benha University, Benha, Egypt \\ Email: aref70@hotmail.com
}

Received June 19, 2012; revised July 21, 2012; accepted July 31, 2012

\begin{abstract}
October oil field is one of the largest hydrocarbon-bearing fields which produces oil from the sand section of the Lower Miocene Asl Formation. Two marl (Asl Marl) and shale (Hawara Formation) sections of possible source enrichment are detected above and below this oil sand section, respectively. This study aims to identify the content of the total organic carbon based on the density log and a combination technique of the resistivity and porosity logs $(\Delta \log \mathrm{R}$ Technique). The available geochemical analyses are used to calibrate the constants of the TOC and the level of maturity (LOM) used in the ( $\Delta \log \mathrm{R}$ Technique). The geochemical-based LOM is found as 9.0 and the calibrated constants of the Asl Marl and Hawara Formation are found as 11.68, 3.88 and 8.77, 2.80, respectively. Fair to good TOC\% content values $(0.88$ to 1.85 ) were recorded for Asl Marl section in the majority of the studied wells, while less than $0.5 \%$ is recorded for the Hawara Formation. The lateral distribution maps show that most of the TOC\% enrichments are concentrated at central and eastern parts of the study area, providing a good source for the hydrocarbons encountered in the underlying Asl Sand section.
\end{abstract}

Keywords: Total Organic Carbon; Source Rocks; Well Logs; October Oil Field; Gulf of Suez

\section{Introduction}

October Field is the third largest field in Egypt. It is structurally trapped in a complex of rotated fault blocks $[1,2]$, a common scenario throughout the Gulf of Suez. The main oil reservoirs are the Carboniferous to Lower Cretaceous Nubia sandstone and the Miocene Asl sandstone [3]. It consists of many marine platforms which produces oil from different reservoirs of different geologic ages.

The first platform (A) was installed in 1977 at the southwestern block of October concession, after the discovery of GS 195-1 well (OCT-A1). This well had an initial production rate of 14.000 BOPD from Nubia oil reservoir [4]. This is followed by establishing many other northward platforms (B, C, D and G) to define and examine the northern limits of Nubia and Nukhul reservoirs [5]. In 1989, the Asl reservoir sand (Miocene) was discovered by the drilling of NO 183-1 well, on the hanging wall of a large normal fault bounding the west of October field. From this date and upcoming a large number of wells were drilled in this newly discovered "J" named platform and around it [6].

Asl Formation is subdivided into two zones; an upper zone which consists mainly of marl (Asl Marl) and a lower zone of complete sand lithology (Asl Sand). Asl Sand zone is considered the main oil reservoir in the study area. Meanwhile, the marl section of the Asl formation and the shales of Hawara formation are considered the main possible sources rocks in October field area.

Source rocks are commonly shales and lime-mudstones that contain significant amounts of organic matter. Non-source rocks also contain organic matter, but the amount is generally not significant [7]. Good hydrocarbon source rocks must contain organic matter higher than $1 \%$ (wt $\%$ TOC). These organic materials could only generate hydrocarbons, if they reach a level of thermal maturation high enough to generate and expel comercial quantities of oil and/or gas [8].

Well logging methodology in geochemical evaluation is very important technique not only for its usefulness as a quick scan of potential source rock, but also in its ability to identify the organic richness (TOC\%) of these rocks [7,9-18].

Many authors had studied the possible source rocks of the Gulf of Suez. The most important is the work done 
by [19] in which the Globigerina Marls of Lower Miocene age is suggested to be the possible source rocks of all the oil in the Gulf of Suez. Shahin and Shehab [20] pointed out that Campanian brown limestone and Paleocene Esna shale, besides some intervals of Matulla Formation are the most prolific oil sources among the PreMiocene rocks. Moreover they suggested some intervals of Lower Miocene age to be the source of the oil in southern portion of Gulf of Suez. Soliman [21] carried out some geochemical analysis over some samples collected from October Field. Shahin [22] said that PreMiocene sediments are the main source of hydrocarbons in the northern parts of Gulf of Suez. He pointed out that intervals from Nubia, Matulla, Wata, Sudr, Esna and Thebes Formations, although they have a wide range of age, but still simultaneously active within the hydrocarbon generation limits. He also found that the time of oil expulsion and migration postdates the deposition of South Gharib Formation, which represents the seal rock of the Miocene reservoirs. In the complied report of the US Geological Survey (world energy project), Lindquist [8] had clarified that two major oil sources for the hydrocarbons in the Red Sea and Gulf of Suez were indicated. The first is the Campanian Sudr (Brown/Dawi) source rocks, while the second is the Middle Miocene Maqna source rocks. Another important work was done also by $[23,24]$.

This study aims mainly to investigate the organic richness and to estimate the total organic carbon content (TOC\%) of the Asl Marl section and Hawara Formation using a methodology based on the density log and combination of the resistivity and porosity tools. Nine wells with complete well logging data sets are utilized for this purpose (Figure 1).

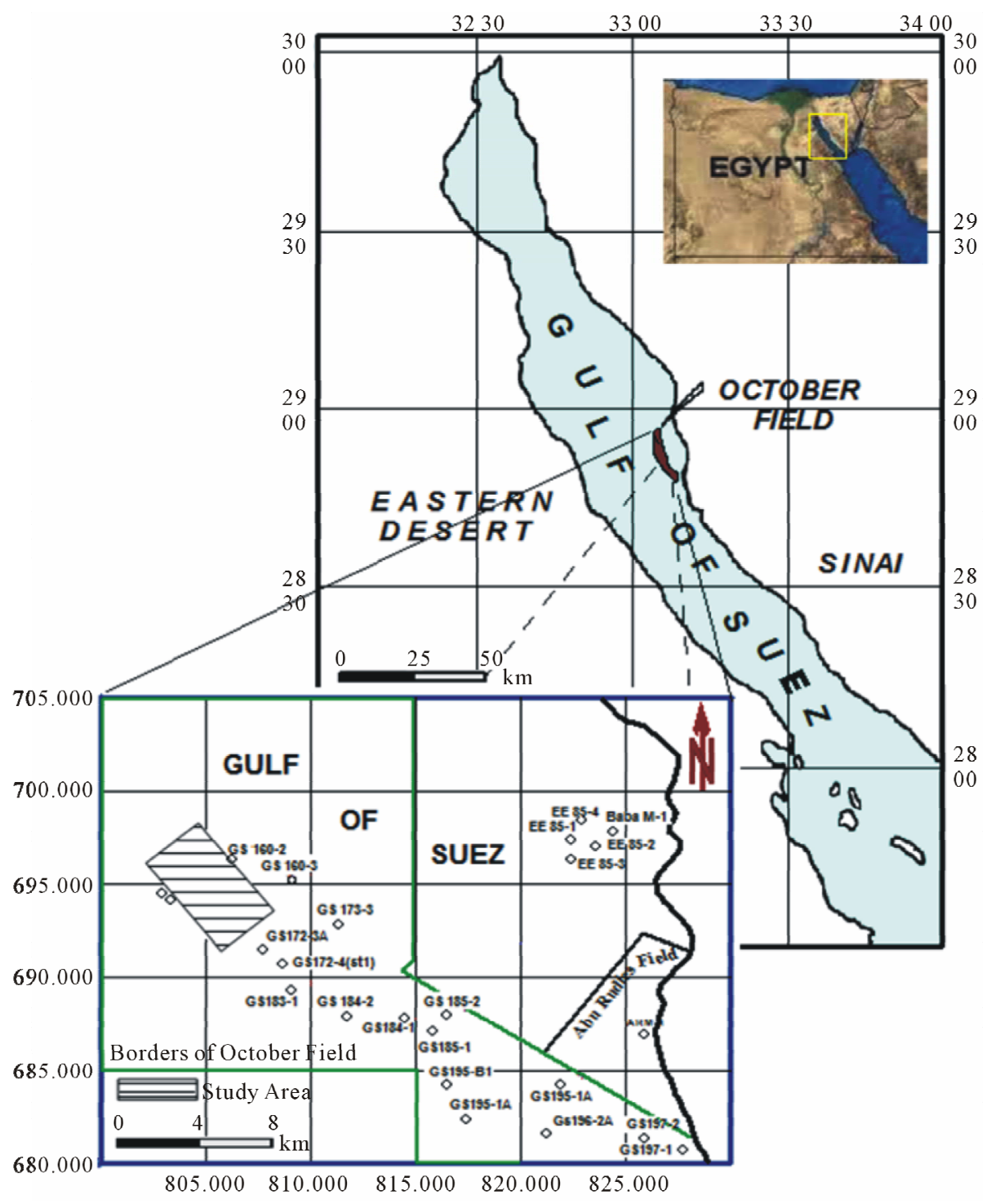

Figure 1. Location map of October oil field, Gulf of Suez-Egypt. 


\section{Geologic Setting}

The Gulf of Suez graben or rift basin was created by stretching and collapse of the crust. This process is often associated with hydrocarbon accumulation. Subsidence moves potential source rocks to depths suitable for oil and gas generation and the stretching motion can produce structural traps in the fault blocks, which characterize rift basins [2,3,25-29]. The Gulf of Suez is subdivided into three structural provinces according to their structural setting and regional dip direction and separated from each other by two NNE-SSW hinge zones [1]. They are from north to south Ataqa, Gharib and Zeit provinces (Figure 2).

The stratigraphic sequence of the Gulf of Suez has been studied by many workers. It ranges in age from Pre-Cambrian to Recent. Figure 3 shows the generalized stratigraphic column of northern Gulf of Suez in which three depositional phases are generally assumed [30].
The first comprises the deposition of formations ranging in age from a postulated Devonian to Eocene. These formations, which include the Nubia Sandstone, are important as reservoir rocks and to a lesser extent as source rocks. The second phase is represented by the Lower Miocene and is characterized by its overall excellent qualities as source, reservoir and seal rocks. The third phase represents formations of Middle Miocene to Pliocene in age. This phase closes the depositional history of the Suez graben area.

In the present study we focused mainly on the marl and shale sections of the Lower Miocene rocks of the Asl and Hawara formations.

\section{Response of Logs to Organic Matter}

Organic-rich rocks are usually composed of three components i.e., rock matrix, solid organic matter and the fluid(s) filling the pore space, while non-source rocks are

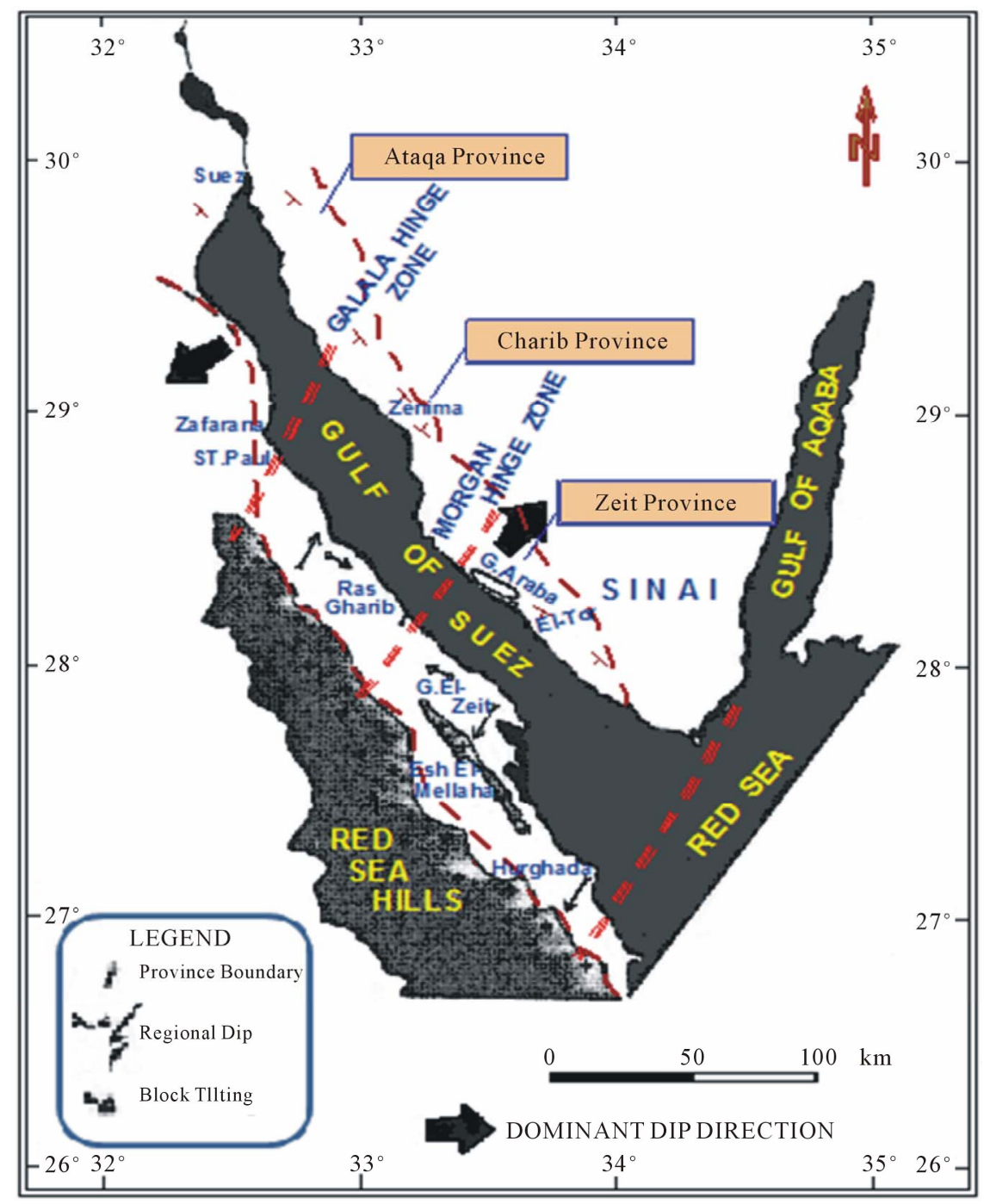

Figure 2. Structure provinces of Gulf of Suez (after EGBC and Biecip, 1988). 


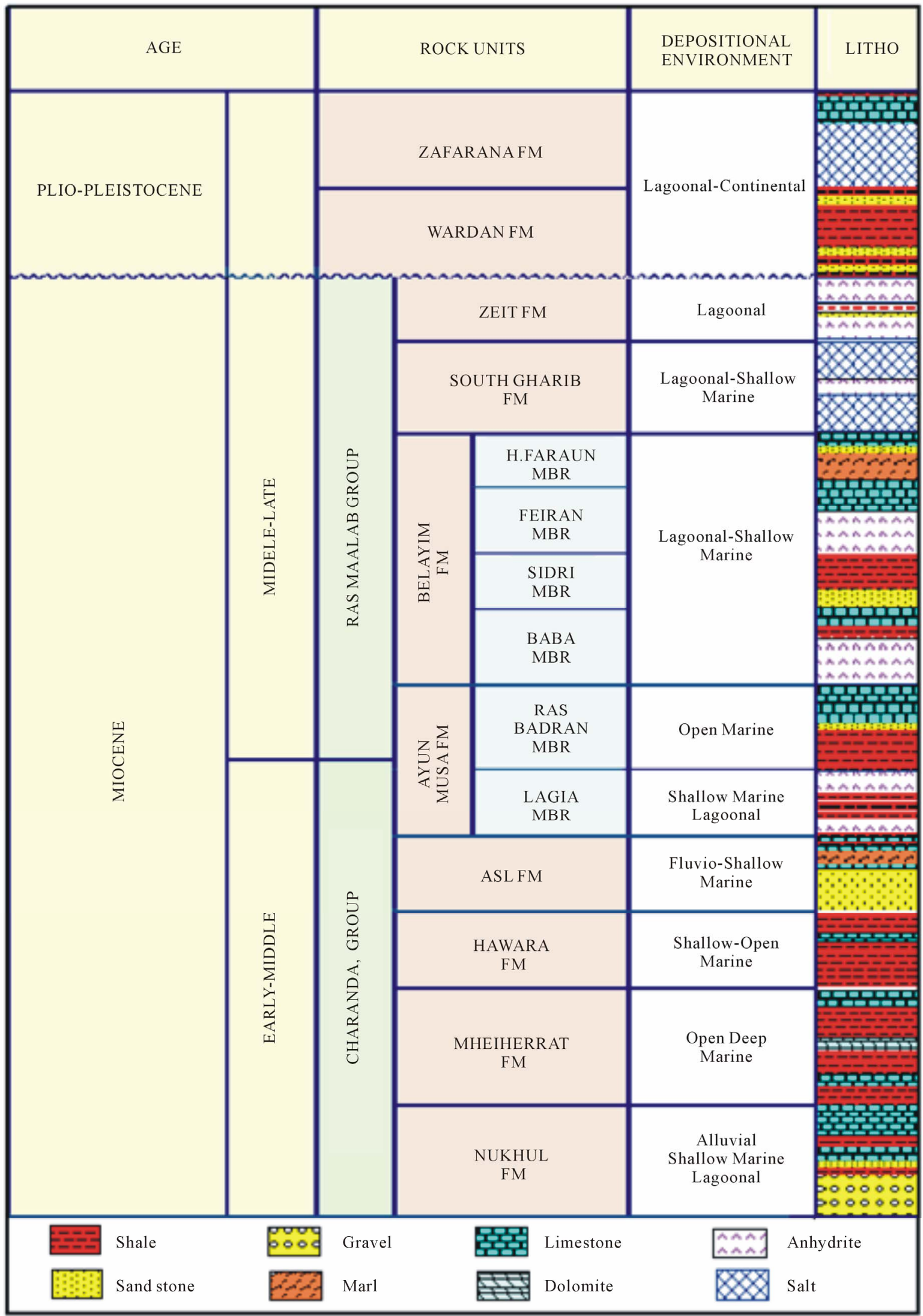

Figure 3. A generalized stratigraphic column of the Gulf of Suez. 
composed primarily of only two components i.e., the rock matrix and the fluid filling the pore space. As the source rock matures, a portion of the solid organic matter is transformed to liquid hydrocarbons which move into the pore space displacing the formation water. This is essentially the model described by [31-35]. These physical transformations affect the porosity, density and resistivity of the rocks and hence reflected in their electric logs [7]. According to the classification made by [36], the potentialities of source rocks on basis of organic carbon richness can be classified as follows; poor source rock $(\mathrm{TOC} \%<0.5)$, faire source rock (TOC\% $0.50-1.0)$, good source rock (TOC\% $1.0-2.0)$ and excellent source $\operatorname{rock}(\mathrm{TOC} \%>2.0)$.

\section{Methods of Study}

In the present study the total organic carbon is estimated using two different methods. The first ( $\Delta \log \mathrm{R}$ Technique) is proposed by [7,9] and depends on the combination of resistivity with porosity logs, while in the second method of [11], the organic carbon content (TOC\%) is related to the density log only. In the following section, a detailed description of both methods will be provided.

\section{1. $\Delta \log R$ Technique}

This technique was first developed and tested within EXXON/ESSO beginning in 1979. Since that, it has been successfully applied to many wells worldwide. It is found to work adequately in both carbonate and clastic source rocks, and can be accurate in predicting $\mathrm{TOC} \%$ over a wide range of maturities [9]. The method employs the overlaying of a properly scaled porosity log (Sonic, Density or Neutron) on a resistivity curve (preferably from deep reading tool). The organic-rich intervals can be then recognized by the separation and non-parallelism between these two curves $(\Delta \log \mathrm{R})$. Passey et al. [7] proposed the following algebraic expression for the calculation of $\Delta \log \mathrm{R}$ from Sonic/Resistivity overlay:

$$
\Delta \log \mathrm{R}=\log 10(\mathrm{Rt} / \mathrm{Rtbl})+0.02 *(\Delta \mathrm{t}-\Delta \mathrm{tbl})
$$

where, $\Delta \log \mathrm{R}$ is the curve separation measured in logarithmic resistivity cycles, $\mathrm{Rt}$ is the true resistivity log reading, $\Delta t$ is the sonic log reading, $\mathrm{Rtbl}$ and $\Delta \mathrm{tbl}$ are the base-lined resistivity and sonic readings in front of nonsource shale, and 0.02 is a constant based on the ratio of $50 \mu \mathrm{sec} / \mathrm{ft}$ per one resistivity cycle.

Density and neutron curves can be also scaled in combination with the resistivity curve in a similar way to that used in the sonic/resistivity combination. The total organic carbon (TOC\%) can be then calculated as follows:

$$
\mathrm{TOC} \%=(\Delta \log \mathrm{R}) * 10(2.297-0.1688 * \mathrm{LOM})
$$

where, TOC is the total organic carbon content and LOM is the level of maturity (ranges between 7 and 12 for mature oil).

\subsection{Density Log Method}

Density log method was applied to estimate the total organic carbon content (TOC\%) for the two studied formations. The following equation of [11] is used to estimate the total organic carbon content:

$$
\mathrm{TOC} \%=\mathrm{A} / \Delta \mathrm{blog}-\mathrm{B}
$$

where, $\Delta \mathrm{blog}$ is the density log reading, and $\mathrm{A}$ and $\mathrm{B}$ are constants varying depending on the formation of interest.

\subsection{Calibration with Geochemical Analyses}

In the present study, the available geochemical analyses obtained from the geochemical analysis of some of the drilled wells in October Filed area, are used to calibrate both of the constants (A and B) of the density log method [11] and the level of maturity of the hydrocarbon (LOM) that is used in the $\Delta \log \mathrm{R}$ technique [9]. Based on the geochemical analyses, the utilized $\mathrm{A}$ and $\mathrm{B}$ constants are found to be 11.68 and 3.88 for Asl formation, and 8.77 and 2.80 for Hawara formation, while the level of maturity is taken as 9.0 .

\section{Results and Discussions}

Table 1 illustrates the different $\Delta \mathrm{T}-\mathrm{R}$ constants and the estimated TOC $\%$ values as concluded from both methods. Although there are some differences in the calculated TOC $\%$ values obtained by $[9,11]$, still these values are in the same organic richness range. Based on the obtained results by and depending on [36] classification Asl Marl section is classified as faire to good source rock, while Hawara Formation is regarded as poor source rock. The following is a detailed evaluation of the concluded results.

\subsection{Evaluation of Total Organic Carbon Content (TOC)}

Figures 4-8 show the organic richness analyses for some selected wells in the study area, besides their interpretation and representation vertically with depth. Each figure reveals the different interpreted $\Delta \log \mathrm{R}$ separations (Tracks 2, 3 and 4) and the final deduced TOC\% values using both techniques (Track 5). The values obtained from Passey method are used only in final interpretation because it gives more reliable results than the other methods.

\subsubsection{Asl Marl Section}

Good variable TOC content values ( 0.88 to 1.85$)$ were recorded for Asl Marl section in the majority of the studied 
Table 1. The different $\Delta \log R$ constants and the estimated TOC \% values as concluded from Passey and Schmoker methods.

\begin{tabular}{|c|c|c|c|c|c|c|c|c|c|}
\hline \multirow{3}{*}{ No } & \multirow{3}{*}{ Well } & \multirow{3}{*}{\multicolumn{2}{|c|}{ Formation }} & \multicolumn{4}{|c|}{ (log R) Constants } & \multirow{3}{*}{$\begin{array}{c}\text { TOC } \% \text { Passey } \\
\left(\begin{array}{c}\text { Using Geochemical } \\
\text { value of } L O M=9)\end{array}\right.\end{array}$} & \multirow{3}{*}{$\begin{array}{c}\text { TOC } \% \text { Schmoker } \\
\begin{array}{c}\text { (Using Geochemical } \\
\text { derived constants) }\end{array}\end{array}$} \\
\hline & & & & & (Pass & Method) & & & \\
\hline & & & & $\Delta \mathrm{Tlog}$ & $\rho b \log$ & $\phi \mathrm{Nlog}$ & Rtbase & & \\
\hline \multirow{3}{*}{1} & \multirow{3}{*}{ GS172-2 } & \multirow{3}{*}{ Asl } & Marl & & & & & 0.990 & 0.750 \\
\hline & & & Sand & 95 & 2.50 & 41 & 1.00 & ---- & ---- \\
\hline & & & & & & & & 0.620 & 0.540 \\
\hline \multirow{3}{*}{2} & & \multirow{2}{*}{ Asl } & Marl & & & & & 1.100 & 0.920 \\
\hline & J2ST1 & & Sand & 95 & 2.54 & 36 & 1.10 & ---- & ---- \\
\hline & & & & & & & & 0.450 & 0.560 \\
\hline \multirow{2}{*}{3} & \multirow[b]{2}{*}{$\mathrm{J} 3 \mathrm{~A}$} & Asl & Marl & \multirow[b]{2}{*}{87} & \multirow{2}{*}{2.54} & \multirow{2}{*}{35} & \multirow{2}{*}{1.30} & 1.851 & 1.234 \\
\hline & & & & & & & & 0.470 & 0.570 \\
\hline \multirow{3}{*}{4} & \multirow{3}{*}{ J4ST2 } & \multirow{3}{*}{ Asl } & Marl & & & & & 1.260 & 1.030 \\
\hline & & & Sand & 96 & 2.52 & 46 & 1.20 & ---- & ---- \\
\hline & & & & & & & & 0.370 & 0.630 \\
\hline \multirow{3}{*}{5} & & \multirow{3}{*}{ Asl } & Marl & & & & & 1.160 & 0.900 \\
\hline & J5 & & Sand & 98 & 2.45 & 35 & 0.82 & ---- & ---- \\
\hline & & & & & & & & 0.630 & 0.680 \\
\hline \multirow{3}{*}{6} & & \multirow{3}{*}{ Asl } & Marl & & & & & 1.790 & 1.700 \\
\hline & J6A & & Sand & 95 & 2.50 & 36 & 1.10 & ---- & ---- \\
\hline & & & & & & & & 0.470 & 0.590 \\
\hline \multirow{3}{*}{7} & & \multirow{3}{*}{ Asl } & Marl & & & & & 0.980 & 0.810 \\
\hline & J7A & & Sand & 98 & 2.52 & 36 & 1.15 & ---- & ---- \\
\hline & & & & & & & & 0.530 & 0.610 \\
\hline \multirow{3}{*}{8} & & \multirow{3}{*}{ Asl } & Marl & & & & & 1.110 & 1.161 \\
\hline & No $159-1$ & & Sand & 100 & 2.48 & 35 & 1.00 & ---- & ---- \\
\hline & & & & & & & & 0.650 & 0.690 \\
\hline \multirow{3}{*}{9} & & \multirow{2}{*}{ Asl } & Marl & & & & & 0.870 & 0.804 \\
\hline & No $159-2$ & & Sand & 95 & 2.56 & 38 & 1.20 & ---- & ---- \\
\hline & & & & & & & & 0.550 & 0.450 \\
\hline
\end{tabular}

wells. Regarding these figures, a rightward big deflection of the resistivity log on the expense of the porosity logs in front of the shale and marl intervals can be seen.

\subsubsection{Asl Sand Section}

Although no organic materials were recorded in the Asl Sand section, but still $\Delta \log R$ technique of prime importance in front of this zone. It can be used as a powerful qualitative technique for identifying its oil-bearing characteristics of the Asl Sand section as follows:

\section{- Oil-Bearing Asl Sand}

Asl Sand is composed mainly of sandstone with no reasonable organic matter. Figure 4 shows the $\Delta \log R$ separation in front of the oil-bearing Asl Sand in GS 172-2 well. Good hydrocarbon deflection associated with large $\Delta \log \mathrm{R}$ separations is observed in front of the oil zone.

\section{- Water-Bearing Asl Sand}

$\Delta \log \mathrm{R}$ separation in case of water-bearing sand is shown in NO 159-1 well (Figure 5). The resistivity (leftward deflection) and porosity logs (rightward deflection) enhance a good separation in opposite directions to that 


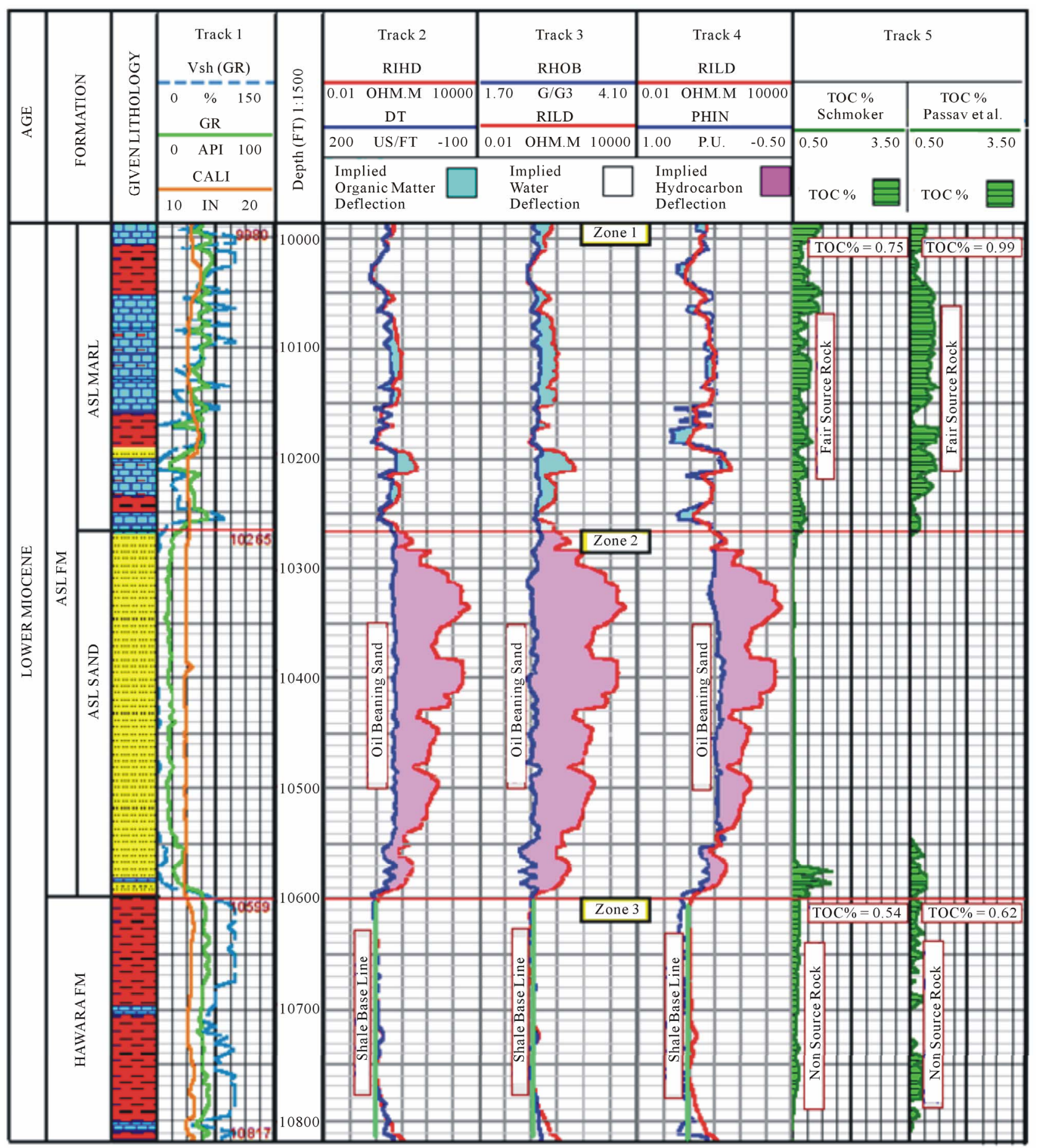

Figure 4. The estimated total carbon content (TOC\%) of GS 172-2 well. The oil-bearing nature of Asl Sand section is also indicated.

of hydrocarbons.

\section{- Oil-Water Contact}

A suggested oil-water contact is well observed in the Asl Sand section of J6A well at depth $11055 \mathrm{ft}$ (Figure 6). The upper part of Asl Sand in this well exhibits good hydrocarbon saturations (rightward deflection of resisti- vity $\log$ ) while the lower part attains $100 \%$ water saturation (leftward deflection of resistivity log).

\subsubsection{Hawara Formation}

No $\Delta \log \mathrm{R}$ separation is observed, as both of the resistivity and porosity curves are base-lined indicating non- 


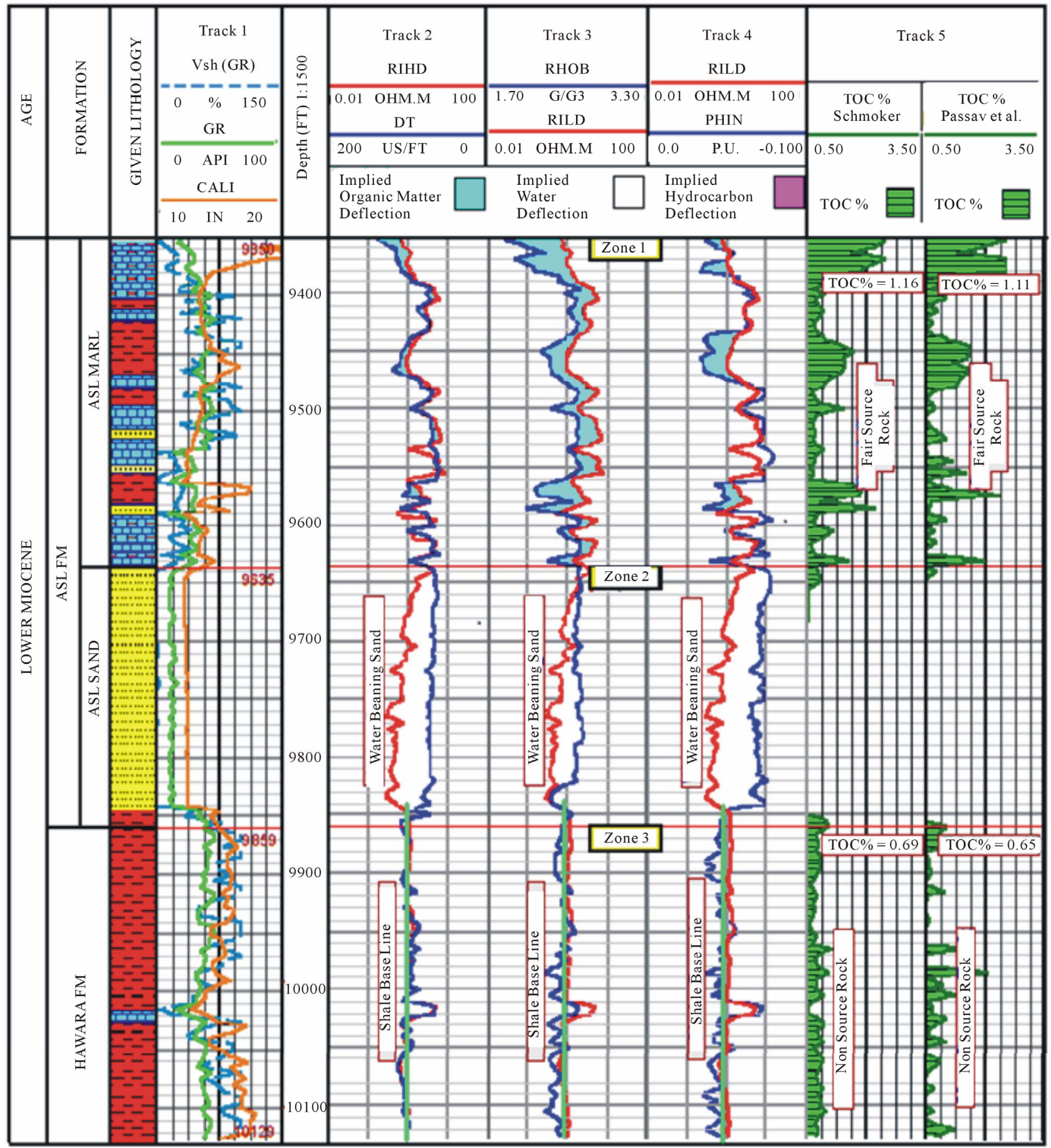

Figure 5. The estimated total carbon content (TOC\%) of NO 159-1 well. The water-bearing nature of Asl Sand section is also indicated.

source nature of this formation.

\subsection{Lateral Distribution of Total Organic Carbon Content TOC\%}

Two lateral distribution maps of total organic matter were constructed for the Asl Marl section and Hawara shale Formation (Figures 7 and 8). The TOC $\%$ distribution map for Asl Marl section shows decreasing towards the north and south margins of the study area (as indicated by arrows in the map), while a well observed increase is recorded at the central and eastern parts (anomalies A and $\mathrm{B}$ ). The maximum $\mathrm{TOC} \%$ is recorded at $\mathrm{J} 3 \mathrm{~A}$ well $(1.85 \%)$ while a minimum value of $0.87 \%$ is 


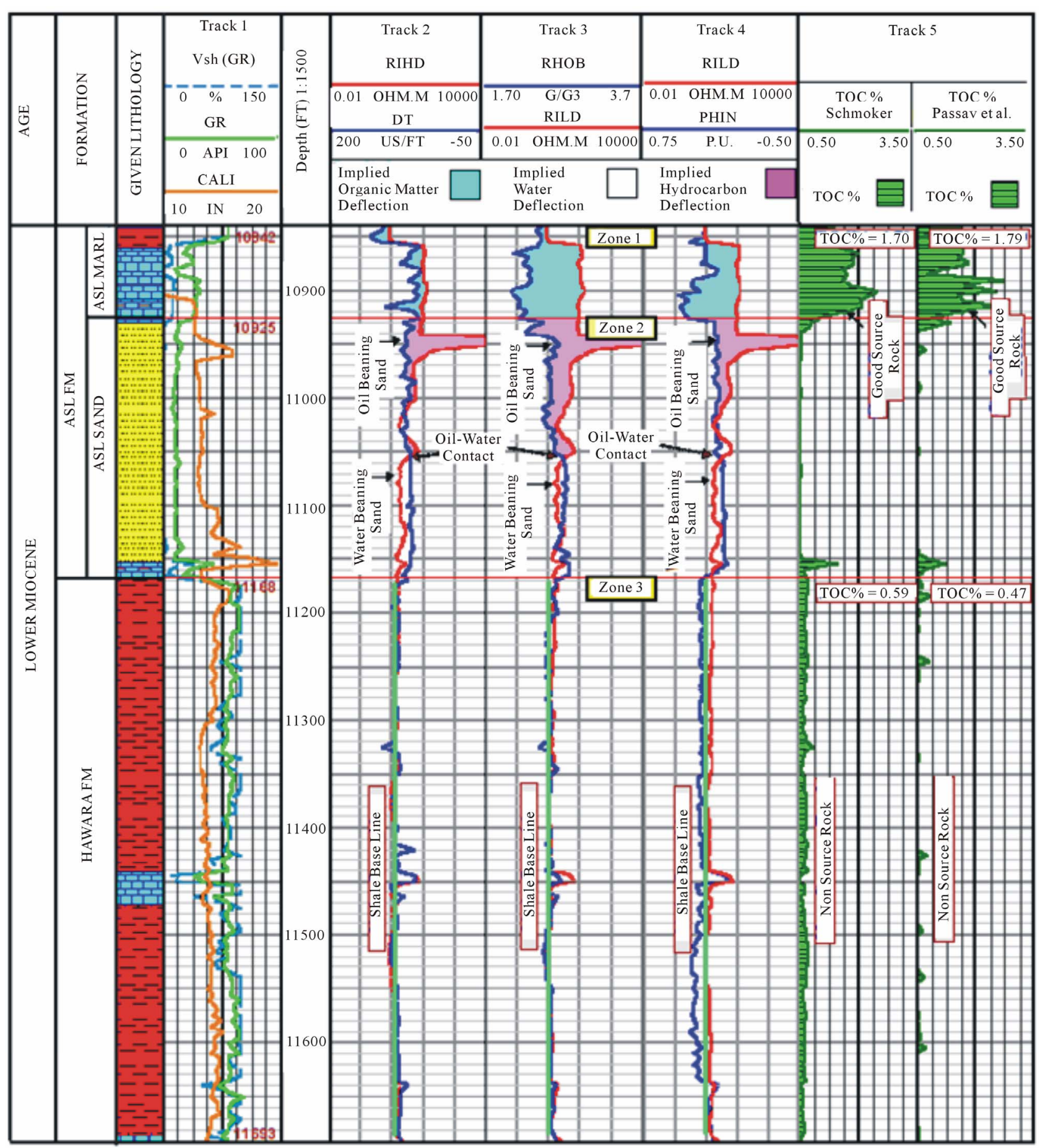

Figure 6. The estimated total carbon content (TOC\%) of J6A well showing the oil-water contact clearly.

exhibited in NO 159-2 well (Figure 7). The TOC\% map of Hawara Formation (Figure 8) reveals a very low content of TOC $\%$ of less than $1 \%$ indicating the non-source rock characteristics of this formation. Two very low anomalies $(\mathrm{C}$ and $\mathrm{D})$ are well recognized with a minimum TOC $\%$ value of $0.37 \%$ at J4ST2 well. A maximum TOC $\%$ value of $0.65 \%$ is recorded at NO $159-1$ well.

\section{Conclusions}

This study aimed mainly to investigate the upper part of Asl Formation (Asl Marl) and the underlying Hawara Formation as possible source rocks. Nine wells with complete well logging suites are used in this study. Total organic carbon was determined using two different methods (Schmoker and Hester, 1983 and $\Delta \log$ R Tech- 


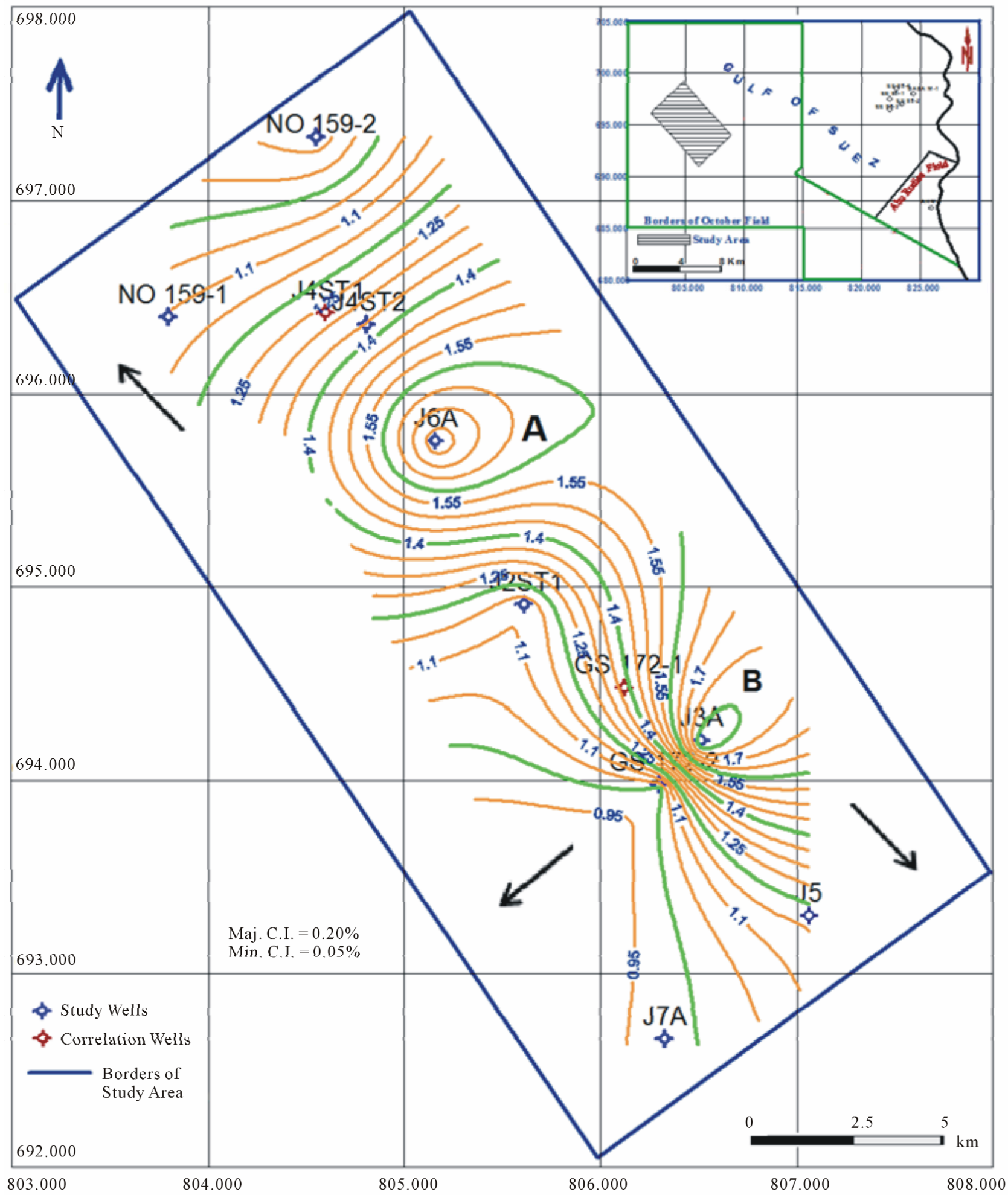

Figure 7. TOC\% lateral distribution map of the Asl Marl section, in the study area.

nique of Passey et al. 1990). The main concluded results from this study can be summarized as:

- A geochemical-based level of maturity (LOM) of 9.0 is used for calculating the total carbon content (TOC $\%$ ).
- A good TOC\% content in assigned for the Asl Marl section (0.88 to 1.85$)$.

- Fair-to-poor content (less than 1\%) for the Hawara Formation. 


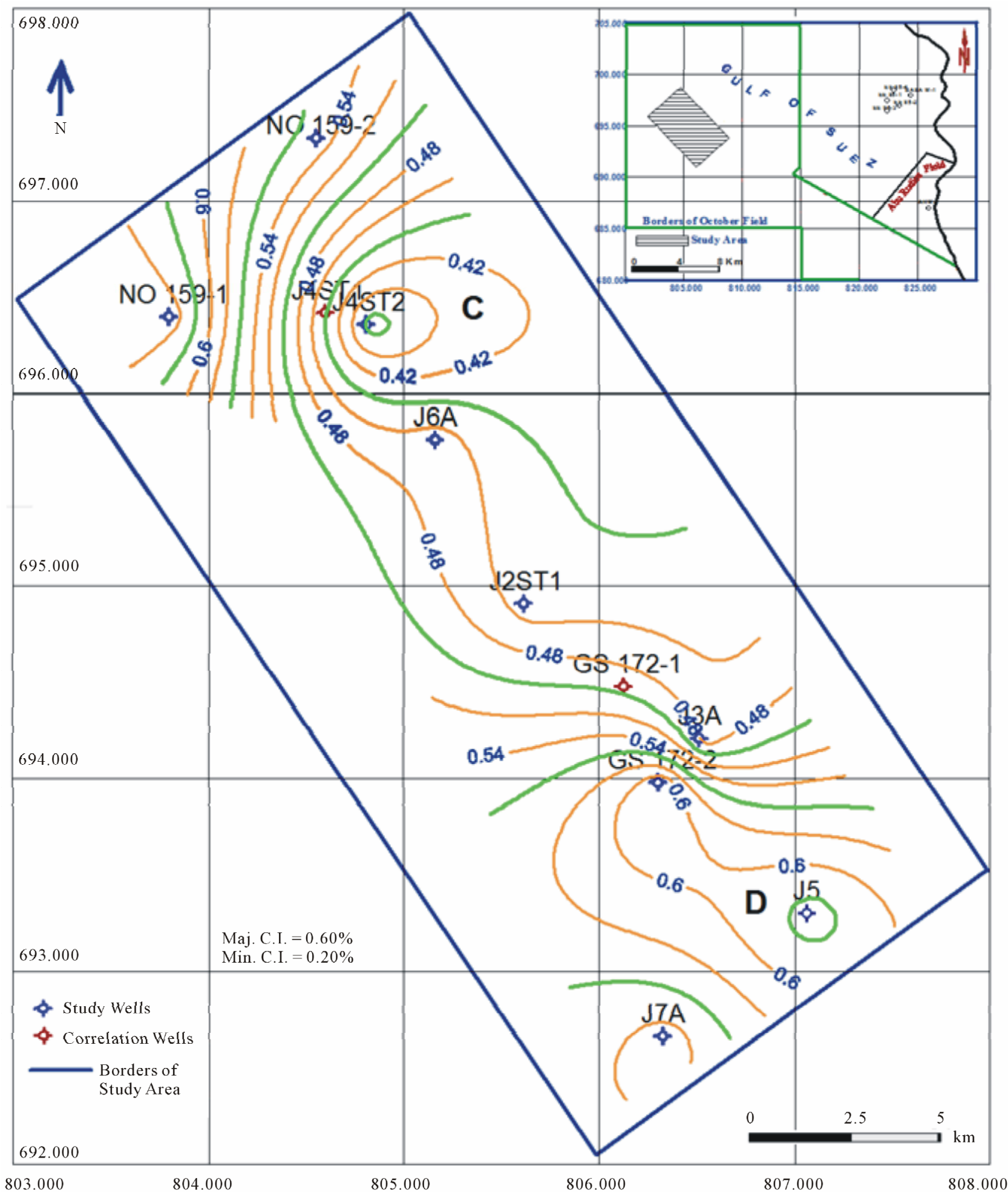

Figure 8. TOC\% lateral distribution map of Hawara Formation, in the study area.

- The distribution maps of the TOC\% show a good concentration of $\mathrm{TOC} \%$ at the central and eastern parts of the study area and low content at the northern and southern margins.
- Due to its relative enrichment in the TOC\% content, the Asl Marl section is considered a possible source of the implied hydrocarbons in the underlying Asl Sand section. 


\section{Acknowledgements}

This work is supported by the Scientific Research Centre, College of Sciences, King Saud University.

\section{REFERENCES}

[1] EGPC and Biecip, "Structural Evolution and Tectonic Modeling in the Gulf of Suez," Internal Report, 1988.

[2] A. Rashed, "The Main Fault Trends in the Gulf of Suez and Their Role in Oil Entrapment," 10th Petroleum Exploration and Production Conference, Cairo, No. I, 19-22 November 1990, pp. 143-178.

[3] Schlumberger, "Well Evaluation Conference-Egypt," Houston, $1995,87 \mathrm{p}$.

[4] Gupco, "The Geology of October 'D' Platform Well Area. Gupco," Internal Report, 1982.

[5] Gupco, "October G-1 Well Recommendation. Gupco," Internal Report, 1987.

[6] Gupco, "Oil Fields in Gulf of Suez. Gupco," Internal Report, 1994.

[7] Q. R., Passey, S., Creany, J. B, Kulla, F. J., Moretti and J. D, Stroud, “A Practical Model for Organic Richness from Porosity and Resistivity Logs," AAPG, Vol. 74, No. 12, 1990, pp. 1777-1794.

[8] J. S., Lindquist, "The Red Sea Basin Province: SudrNubia and Maqna Petroleum Systems," US Department of Interior, US Geological Survey, Open File Report No. 99-50-A, 1889, 21 p.

[9] Q. R. Passey, S. Creany, J. B. Kulla, F. J. Moretti and J. D. Stroud, "Well Log Evaluation of Organic Rich Rocks," 14th International Meeting on Organic Geochemistry, Paris, 18-22 September 1989, Abstract 75.

[10] J. W. Schmoker, "Determination of Organic Content of Appalachian Devonian Shales from Formation Density Logs," AAPG Bulletin, Vol. 63, 1979, pp. 1504-1537.

[11] J. W. Schmoker and T. C. Hester, "Organic Carbon on Bakken Formation, United States Portion of Williston Basin," AAPG Bulletin, Vol. 67, No. 12, 1983, pp. 21652174.

[12] R. Hills, "Quantification of Tertiary Exhumation in the United Kingdom South North Sea Using Sonic Velocity Data," AAPG Bulletin, Vol. 79, No. 1, 1995, pp. 130-159.

[13] D. L. Hall, W. Shentwu, M. Sterner and P. D. Wagner, "Using Fluid Inclusions to Explore for Oil and Gas," Hart's Petroleum Engineer International, Vol. 11, 1997, pp. 29-34.

[14] H. Zhao, N. B. Givens and B. Curtis, "Thermal Maturity of the Barnett Shale Determined from Well-Log Analysis," AAPG Bulletin, Vol. 91, No. 4, 2007, pp. 535-549. doi:10.1306/10270606060

[15] M. Faqira, A. Bhullar and A. Ahmed, "Silurian Qusaiba Shale Play: Distribution and Characteristics," $A A P G$ Heidelberg Conference, Austin, 2010, 2 p.

[16] O. Kavak, J. Connan, N. Y. Erik and M. N. Yalçin, "Organic Geochemical Characteristics of Şırnak Asphaltites in Southeast Anatolia, Turkey," Oil shale, Vol. 27, No. 1,
2010, pp. 58-83.

[17] M. Shayesteh, "Source Rock Analysis from Well Logs in the Southern Dezful Embayment," The 2nd South Asian Geoscience Conference and Exhibition, GEOIndia, Gearter Noida, New Delhi, 2011, 4 p.

[18] J. Jia, Z. Liu, Q. Meng, R. Liu, P. Sun and Y. Chen, "Quantitative Evaluation of Oil Shale Based on Well Log and 3-d Seismic Technique in the Songliao Basin, Northeast China," Oil Shale, Vol. 29, No. 2, 2012, pp. 128-150. doi:10.3176/oil.2012.2.04

[19] J. E. Bobbit and J. D. Gallagher, "The Petroleum Geology of the Gulf of Suez," 10th Annual Offshore Technical Conference, Houston, 8-10 May 1978, pp. 375-380. doi:10.4043/3091-MS

[20] A. N. Shahin and M. M. Shehab, "Petroleum Generation, Migration and Accumulation in the Gulf of Suez Offshore, Sinai," 6th E.G.P.C, Exploration Seminar, Vol. 1, 1984, pp. 126-152.

[21] O. M. Soliman, "Petroleum Habitat in the Vicinity of October Oil Field, Gulf of Suez," Unpublished MSc Thesis, Suez Canal University, Suez Canal, 1988.

[22] A. N. Shahin, "Oil Windows in the Gulf of Suez Basin, Egypt," AAPG Bulletin, Vol. 72, 1988, 14 p.

[23] B. G. Rhorback, "Crude Oil Geochemistry of the Gulf of Suez," 6th E.G.P.C Exploration Seminar, Vol. 1, 1982, pp. 212-224.

[24] M. G. Barakat, M. Darwish, A. Hassouba and M. Salah, "Rifting-Related Sequences and Hydrocarbon Habitat in the Southern Gulf of Suez and Northern Red Sea Province, Egypt," 2nd International Conference, Geology of the Arab World, Cairo University, Cairo, 1994, pp. 157184.

[25] M. Abd El-Gawad, "The Gulf of Suez: A Brief Review of Stratigraphy and Structure," Philosophical Transactions of the Royal Society, No. A267, 1970, pp. 41-48. doi:10.1098/rsta.1970.0022

[26] M. Hagras, "Some Geological Observation in the Gulf of Suez Area, Egypt," 8th E.G.P.C, Exploration Conference, Cairo, November 1986.

[27] W. Meshref, M. Abu El-Karamat and M. El-Gindi, "Exploration Concept for Oil in the Gulf of Suez," 9th E.G.P.C, Exploration Conference, Cairo, November 1988.

[28] A., Lashin and M. Abd El Aal, "Seismic Data Analysis to Detect the Depositional Process Environment and the Structural Framework of East Central Part of Gharib Province, Egypt," Annals of Geological Survey of Egypt, Vol. 27, 2004, pp. 523-550.

[29] A. Lashin, N. Al-Arifi and N. Abu, "Ashour, Evaluation of the Asl and Hawara Formations Using Seismic and Log-Derived Properties, October Oil Field, Gulf of Suez-Egypt," Arabian Journal of Geosciences, Vol. 4, No. 3-4, 2011, pp. 365- 383. doi:10.1007/s12517-009-0065-X

[30] Schlumberger, "Well Evaluation Conference," Egypt. France, 1984, $60 \mathrm{p}$.

[31] G. T. Philippi, "On the Depth Time, and Mechanism of Petroleum Generation," Geohimica et Cosmochimica Acta, Vol. 29, 1968, pp. 1021-1049. 
doi:10.1016/0016-7037(65)90101-8

[32] R. P. Nixon, "Oil Source Beds in Cretaceous Mowry Shale of Northwestern Interior United States," $A A P G$ Bulletin, Vol. 57, No. 1, 1973, pp. 136-161.

[33] F. F., Meissner, "Petroleum Geology of the Bakken Formation, Williston Basin, North Dakota and Montana, in the Economic Geology of the Williston Basin," Williston Basin Symposium, Montana Geological Society, 1978, pp. 207-277.

[34] B. L. Meyer and M. H. Nederlof, "Identification of
Source Rocks on Wire-Line Logs by Density/Resistivity and Sonic Transit Time/Resistivity Crossplots," AAPG Bulletin, Vol. 68, 1984, pp. 121-129.

[35] J. D. Mendelson and M. N. Toksoz, "Source Rock Characterization Using Multivariate Analysis of Log Data," Transactions of the 26th SPWLA, Annual Logging Symposium, Paper UU, 1985.

[36] B. M. Thomas, "Geochemical Analysis of Hydrocarbon Occurrences in Northern Peth Basin Australia," AAPG Bulletin, Vol. 63, 1979, pp. 1092-1102. 